\title{
The Role of NGOs in Promoting Sele Help Groups in Kanchipuram District.
}

\author{
${ }^{1}$ D. Arul Paramanandam, ${ }^{2}$ Dr.P.Packirisamy \\ ${ }^{I}$ Research Scholar, Sathyabama University, Chennai \& Asst.Professor P.A.Arts and Science College, Athur, \\ Chengalpattu. \\ ${ }^{2}$ SIVET College, Gourivakkam, Chennai.
}

\begin{abstract}
The research paper focuses on the Role of NGOs in promoting Self Help Groups in Kanchipuram District, of Tamil Nadu. NGOs (Non-Government Organisations) are Self Help Promotion Institutions (SHPI) with a special task of promoting, nurturing, strengthening and monitoring the SHGs. Many studies reveal that the groups promoted by NGOs are relatively performed better than other Agencies. NGOs conduct periodical trainings to its SHG members to promote leadership qualities and income generating activities. SHGs that are getting trainings from NGOs are performing better than others. NGOs are facilitating intermediaries and they could play a significant role in initiating a right enterprise and technical skills to SHGs. Women should be imparted technical knowledge, skill- training and marketing techniques in the process of establishing on an enterprise by them for more sustainability.
\end{abstract}

AB: NGO; NON - GOVERNMENT ORGANISATION

\section{Introduction:}

Self Help Group is a group of 12 to 20 members of women who come forward voluntarily to work together for their socio-economic up liftment. According to Nazrul Choudhry ( Micro Credit Consultant, Foundation ICO, Spain)* " A group is a number of individual people who are like minded are in similar economic and social condition develop and enjoy mutual trust and confidence before or after joining the programme. In this system, the group creates social capital, self esteem and dignity among its members. It creates a sense of discipline, responsibility, solidarity, cooperation and above all a strong mutual trust and human relations that allows its members to take advantage from each other and from the services( credit or noncredit) provided by the programme". It is true in the case of SHGs, but among the group, loans will be individual, no member has to take a loan or default responsibility for other members.

NGOs (Non-Government Organisations) are Self Help Promotion Institutions (SHPI) with a special task of promoting, nurturing, strengthening and monitoring the SHGs. Many studies reveal that the groups promoted by NGOs are relatively perform better than other Agencies

*(Priya Basu 2006: Veera Shekhappa, ET, al 2009)

\section{Study Period:}

The study period is from 2006 to 2012. Most of the Respondents are NGOs Promoted SHGs. with Bank -Linkage model. And the SHGs are more than 5 years old.

\section{District Profile}

Kancheepuram District is one of the Historical Districts of Tamil Nadu. Welcome to the city of thousand temples. Kancheepuram district is situated on the northern East Coast of Tamil Nadu and is adjacent by Bay of Bengal and Chennai city and is bounded in the west by Vellore and Thiruvannamalai district, in the north by Thiruvallur district and Chennai district, in the south by Villuppuram district in the east by Bay of Bengal.

The district has a total geographical area of 4, 43,210 hectares and coastline of $57 \mathrm{Kms}$. Kancheepuram, the temple town is the District head quarters. For administrative reasons, the District has been divided into 3 Revenue Divisions comprising of 8 Taluks with 1214 Revenue villages. For development reasons, it is divided into 13 Development Blocks with 648 Village Panchayats.

\section{OBJECTIVES}

- To analyze the role of NGOs in promoting SHGs in India,

- To compare the NGOs with other Promoting Agencies on performance and functions

- To understand the limitations in the functions of NGOs. 


\section{Methodology}

The study has been conducted with the help of both primary and secondary data. Primary data have been collected from the beneficiaries who have availed loans and other benefits from NGOs. Cronbach's Alpha test is conducted for the study and for analysis and interpretation Chie-square test, variable tests and five point Likert scale have been used and for the primary data collection Convenient Sampling Method has been adopted. And for the Secondary data, visited 13 Block Development Offices (BDO) in Kanchipuram District., Collectorate-Statistical Information centre, Nationalized Banks, and various NGOs who are in promoting Women SHGs, and Punchayat Level Federation Leaders (PLF) and various web sites. In Kanchipuram District as on 31-09-2012, there are 29,268 Self Help Groups are functioning in 13 blocks. And the population size is 600 .

\section{Criteria for SHGs Borrowing From NGOs:}

- The borrowers must be a member of SHGs, which is promoted by the NGO

- Group or members of the SHG should act as the Guarantor for the Loan

- Loan amount should be used for the purpose for which it has been availed

- Limit of loan depends upon the purpose for which the loan is used.

Table:1. Distribution of sample size in Block level at Kanchipuram District:

\begin{tabular}{|l|l|l|l|l|}
\hline S1.No. & Taluk & No.of SHGs & $\begin{array}{l}\text { No.of } \\
\text { Respondents }\end{array}$ & $\%$ \\
\hline 1 & Kanchipuram & 2450 & 50 & 8.3 \\
\hline 2 & Uthiramerur & 2250 & 45 & 7.5 \\
\hline 3 & Kattankulathur & 2868 & 60 & 10 \\
\hline 4 & Achirapakkam & 1940 & 40 & 6.7 \\
\hline 5 & Thirukazhukundram & 2106 & 40 & 6.7 \\
\hline 6 & Chithamur & 1126 & 20 & 3.3 \\
\hline 7 & Sriperumbathur & 2303 & 50 & 8.3 \\
\hline 8 & Madurantakam & 2956 & 60 & 10 \\
\hline 9 & St.Thomas Mount & 2153 & 45 & 7.5 \\
\hline 10 & Thirupporur & 2670 & 60 & 10 \\
\hline 11 & Lathur & 1340 & 25 & 4.2 \\
\hline 12 & Walajabad & 2755 & 55 & 9.2 \\
\hline 13 & Padappai & 2351 & 50 & 8.3 \\
\hline & Total & 29,268 & 600 & $100 \%$ \\
\hline
\end{tabular}

- Source: primary data: and secondary data from BDO offices.

\section{Nabard and Ngos:}

Nabard (National Banking for Agricultural and Rural Development) provides grant assistance of Rs.4, 500/- to NGOs for promotion and linking of each SHG. This amount broadly covers training of members of SHG, stationery for the group, incentive/ part salary pf NGO Staff. In Kanchipuram District, there are 17 NGOs have been registered as Self Help Promotions Institutions(SHPI) As on 31-03-2010, 496, NGOs have been affiliated with Tamil Nadu Corporation for Women Development (TNCWD).

Table:2. Age Composition of Women SHG Members;

\begin{tabular}{|l|l|l|l|}
\hline S1.No. & Age Groups & No.of Respondents & $\%$ \\
\hline 1 & $18-30$ & 264 & 44 \\
\hline 2 & $31-40$ & 208 & 35 \\
\hline 3 & $41-50$ & 84 & 14 \\
\hline 4 & $51-60$ & 44 & 07 \\
\hline & Total & 600 & 100 \\
\hline
\end{tabular}

Source: primary data. 


\section{Skill Training Programme By The Ngos:}

NGOs conduct periodical trainings to its SHG members to promote leadership qualities and income generating activities. SHGs that are getting trainings from NGOs are performing better than others. NGOs conduct two types of trainings. (i) Trainings to SHG members and

(ii) Trainings to SHG leaders.

Trainings impart the members into: *(CRDS)

- Orientation and social awareness

- Micro-credit training

- Identifying and training in income generating activities

- SHG Federation Concept and Panchayat Raj

- Motivation

- Leadership training in SHGs

- Record Maintenance and

- Marketing SHG Products.

These types of trainings and guidance help the SHGs come closer to NGOs for formation and function.

Many SHGs prefer the NGOs for these unique reasons.

TABLE: 3. REASONS FOR SHGs PREFERING NGOs:

\begin{tabular}{|c|l|c|c|}
\hline SL.No. & Reasons for SHGs Prefer NGOs & No. of Frequencies & Percentage $\%$ \\
\hline 1 & Facilitates in Formation & 108 & 18 \\
\hline 2 & Getting Loan from Banks & 104 & 17 \\
\hline 3 & Leadership and skill training & 106 & 18 \\
\hline 4 & Coordination in conducting meeting & 46 & 8 \\
\hline 5 & Helping in Marketing SHG products & 48 & 8 \\
\hline 6 & Easy Access to Banks & 60 & 7 \\
\hline 7 & Guidance by Animators & 44 & 4 \\
\hline 8 & Record Maintenance/ Accounting/Auditing & 24 & 7 \\
\hline 9 & Savings and Repayment & 40 & 3 \\
\hline 10 & Other Reasons & 20 & $100 \%$ \\
\hline & $\quad$ Total & 600 & 7 \\
\hline
\end{tabular}

\section{Sourace: Primary Data}

The involvement of NGOs is inevitable, because of their wider role in helping the SHGs. It helps the SHGs in formation and function and takes them to the banks and helps them in building confidence in group activities. It guides them into a right path to be successful SHGs. NGOs training really help the SHGs to get motivation and empowerment.

Table:4. Caste wise distribution of Respondents.

\begin{tabular}{|l|l|r|l|}
\hline Sl.No. & Caste & No.of Respondents & $\%$ \\
\hline 1 & BC & 88 & 15 \\
\hline 2 & MBC & 192 & 32 \\
\hline 3 & SC & 256 & 43 \\
\hline 4 & ST & 44 & 07 \\
\hline 5 & Others & 20 & 03 \\
\hline & Total & 600 & 100 \\
\hline
\end{tabular}

\section{Source: primary data}

\section{Women's Economic Role}

The neglect of women's economic role resulted in exploitation of women workers; un equal wages between men and women, higher un employment due to loss of jobs in traditional sectors like textiles, mining, manufacturing and household industries. While the country is experiencing faster growth in its Gross Domestic Product (GDP), over $40 \%$ of the Indians do not have bank accounts. *( RBI- 2009) $51 \%$ of marginal farmer have virtually no access to credit.

In this context, the Role of MFIs and NGOs in poverty alleviation, employment generation, empowerment of women and human development are indispensable. One of the SIX basic principles of Governance laid down in the National Common Minimum Programme is "to empower women politically, educationally, economically and legally" (Nagvi 2008:28)* 
NGO can play a decisive role as an effective delivery mechanism in rural development. They have innate advantage to involve people and ensure their participation in the agencies and fellow NGO is added advantage to them.* Stephen.J.K. (2005.

Tabel: 5. IMPACT ON SHG MEMBERS' LIFE STYLE:

\begin{tabular}{|c|c|c|c|c|c|c|}
\hline $\begin{array}{l}\text { IMPACT IN LIFE } \\
\text { STYLE } \\
\end{array}$ & $\begin{array}{l}\text { STRONGLY } \\
\text { AGREE } \\
\end{array}$ & AGREE & DIS-AGREE & $\begin{array}{l}\text { STRONGLY } \\
\text { DIS-AGREE }\end{array}$ & NUETRAL & TOTAL \\
\hline $\begin{array}{l}\text { Improvement in } \\
\text { Quality life }\end{array}$ & $324(54)$ & $228(38)$ & $12(2)$ & 00 & $36(6)$ & $600(100 \%)$ \\
\hline $\begin{array}{l}\text { Improvement in } \\
\text { Economic status }\end{array}$ & $316(52.6)$ & $236(39)$ & $10(1.6)$ & 00 & $38(6.3)$ & $600(100 \%)$ \\
\hline $\begin{array}{l}\text { Improvement in } \\
\text { Decision making }\end{array}$ & $328(54.6)$ & $244(40.6)$ & $8(1.3)$ & 00 & $20(3.3)$ & $600(100 \%)$ \\
\hline $\begin{array}{l}\text { Improvement in } \\
\text { Leadership quality }\end{array}$ & $312(52)$ & $264(44)$ & $6(1)$ & 00 & $18(3)$ & $600(100 \%)$ \\
\hline $\begin{array}{l}\text { Improvement in } \\
\text { Social participation }\end{array}$ & $332(55)$ & $248(41)$ & $4(0.6)$ & 00 & $16(2.6)$ & $600(100 \%)$ \\
\hline $\begin{array}{l}\text { Improvement in } \\
\text { Respect and } \\
\text { Recognition in the } \\
\text { family }\end{array}$ & $286(47.6)$ & $260(43)$ & $14(2.3)$ & 00 & $40(6.6)$ & $600(100 \%)$ \\
\hline
\end{tabular}

\section{Source: PRIMARY DATA}

According to the Table:2 NGOs supported SHGs' members' life styles have tremendous improvement in total quality of life. It seems that the SHGs' schemes have influenced the individual members' standard of living. Most of the members of the SHGs strongly agree (more than 50\%) that total improvement in quality life, economic status, decision making, leadership quality and recognition in the family. It shows a positive outlook on the impact on SHG Members' life.

\section{Role of Ngos in Entrepreneurship Training}

NGOs are facilitating intermediaries and they could play a significant role in initiating a right enterprise and technical skills to SHGs. Women should be imparted technical knowledge, skill- training and marketing techniques in the process of establishing on an enterprise by them for more sustainability. If these inputs are not supported strongly then women are least likely to succeed in taking up any income generating activity on a sustainable basis even after having a desire and need for such activity (Tyagi, 2008).

\section{Ngos in Capacity Planning}

The field study reveals that the NGOs are playing an important role in SHG members' capacity planning. They take a special care and provide various training programmes for the SHG members to enhance their skills and ability. Many study reveals that the member who are trained on in entrepreneurship running the SHGs very successfully then non-trained SHGs. Women empowerment will take place only by capacity planning. For which trainings are essential. Capacity planning* is the process of determining the production capacity needed by an organization to meet changing demands for its products.

TABLE: 6. IMPACT ON CAPACITY PLANNING BY NGOS:

\begin{tabular}{|l|l|l|l|}
\hline SL.NO. & IMPACT ON CAPACITY PLANNING & FREQUENCIES & \% \\
\hline 1 & Strongly Agree & 352 & 59 \\
\hline 2 & Agree & 148 & 25 \\
\hline 3 & Dis - Agree & 56 & 09 \\
\hline 4 & Strongly Dis-Agree & 00 & 00 \\
\hline 5 & No Option & 44 & 07 \\
\hline & & 600 & $100 \%$ \\
\hline
\end{tabular}

Source: Field Study

It is a clear revelation that NGOs' capacity planning schemes have real impact on SHGs. $59 \%$ of respondents strongly agree with the statement. Out of 600 SHG members, 352 respondents are agree with the statement that NGOs are key people in building capacity planning for the SHGs by conducting several trainings and meetings. Capacity planning is to make effective changes to bring out desirable changes in one's life has been a central idea of empowerment.*Alsop, R and Hesnsohn, N (2005). It helps the SHG members into selfreliant and more successful in functioning of SHGs.

Definitions - Supply Chain Management". North Carolina State University. 2006. 
The Role Of Ngos In Promoting Sele Help Groups In Kanchipuram District.

Table: 7 the \% of SHGs promoted by different Organizations

\begin{tabular}{|l|l|l|}
\hline \multicolumn{1}{|c|}{ SHGs Promotion Industry } & Financed by & $\%$ \\
\hline SHGs formed by NGOs & Banks & 72 \\
\hline SHGs formed by NGOs & NGOs & 7 \\
\hline SHGs formed by Banks & Banks & 21 \\
\hline \multicolumn{2}{|l}{} & $100 \%$ \\
\hline
\end{tabular}

Source: primary data:

According to the Table, there are two types of SHG formation by the NGOs.(i) the SHGs formed by NGOs and financed by Banks under SHG-Bank Linkage Model which constitutes $72 \%$ and (ii) SHGs formed and financed by NGOs which represent only $7 \%$.

Table: 8. SHGs Interest Rate for Bank, NGOs and MFIs

\begin{tabular}{|l|l|l|l|}
\hline Description & Bank & NGOs & MFIs \\
\hline Average Interest Rate on Lending in \% & $8.3 \%$ & $10.6 \%$ & $19.1 \%$ \\
\hline Average Interest Rate on Borrowing in \% & $5.3 \%$ & $6.3 \%$ & $6.6 \%$ \\
\hline Net interest Rate spread \% & $\mathbf{3 . 0 \%}$ & $\mathbf{4 . 3 \%}$ & $\mathbf{1 2 . 5 \%}$ \\
\hline Operation Cost as \% of loan & $3.9 \%$ & $2.5 \%$ & $9.6 \%$ \\
\hline
\end{tabular}

(Source: rbi.org.in)

Source: www.rbi.org.

The present interest rate structure is stipulated by NABARD in India at different levels under SHGBank Linkage Model. The transaction cost is the major contributor to the high interest rates in micro credit loan. When we compare the interest rate charged by various Models (Table.5) and we come to know clearly that the interest rates charged by the NGOs are not greater than MFIs.

Aloysius P. Fernandez, (Fernandez, 2008). (Founder of MYRADA the first NGO supported by the NABARD to conduct the pilot study for the SHG movement) one of the pioneers of SHG movement in the country, argue that one of the serious problem of all livelihood promotion programs is that they assume that the poor do not have livelihood strategies of their own and they start with zero. In fact that the poor have their own basket of livelihood strategies and financial needs such as education, purchase livestock, land development, working capital needs in agriculture and other family ventures, business, jewellery, medical expenses, purchase of land, house repairs, house construction,LPG connection,etc

\section{Findings:}

- SHGs formed by NGOs and financed by banks are out numbered than (72\%) other promotional Institutions

- NGOs' supported SHGs are more successful in functioning and consistency

- NGOs' formed SHGs have more positive impact on total quality of life style.

- NGOs conduct more trainings for SHGs

- SHGs supported by NGOs are very prompt in repayment of loan (99\%)

- Capacity planning is a key role played by NGOs

- NGOs supported and financed SHGs are only $7 \%$

- The SHGs are turning out to be quality clients in view of better credit management mobilization of thrift, low transactions cost and full repayments because of NGOs involvement in this programme.

- The platform of NGOs provides different types of financial services to the SHGs.

- Regular meetings and savings are compulsory ingredients in the product system.

- Faster and shorter repayment schedule ensure faster recycling of funds.

Structural Issues:

- Lack of follow -up by the NGOs is an unique failure in the system

- There was no dedicated authority to take care of the needs of the SHGs

- Many NGOs have areas to concentrate.

- Many members showed lack of involvement and commitment towards group activities.

- Absence of effective leadership in SHGs

- Lack of motivation to start up a group enterprise

- Lack of wider market prospects. SHGs sell their product only local market.

- Transaction cost is vary from one NGOs to another 


\section{Recommendations to Ngos:}

- NGOs should play a dedicated role to progress the SHGs function

- Leadership development activities are essential. There should be rotation or change in leadership.

- A workable business strategy should be generated for SHGs

- "Savings first and credit later" this concept should be given priority.

- NGOs should give more priority for capacity planning

- Market oriented approach is essential for SHGs' continuity and stability.

- The transaction cost may be reduced.

- NGOs should examine whether the loan amount has been used for good purpose.

- NGOs should adopt workable strategies to do a lot for SHGs' longevity and sustainability on a long run basis.

- Funding Agencies should have a bird-view approach on the functioning of NGOs.

\section{Conclusion:}

In the present scenario, NGOs are important intermediaries in bringing up SHGs. They are a catalyst in between SHGs and Funding agencies like banks and MFIs. It is realised that the progress of India depends on women empowerment and employment through strong SHG movements. The Role of NGOs' bring a real Impact on the status of women membersin SHGs. The study proves that women SHGs are greatly empowered by group -run enterprise activities promoted by NGOs. However, the study examined the effectiveness of NGOs in promoting SHGs and concluded that it is an essential need for more financial support to SHGs for successful continuity and survival. The Govt, MFIs and NGOs should impart entrepreneurship skills in SHGs for more sustainability and rural economic growth. Economic development will not complete unless women are economically self reliant and developed. The study emphasize that the development of women alone will banish the intensity of poverty. All the agencies that are in the promotion of SHGs in India have to play more attention to women literacy, rural economy and strive hard to eradicate poverty from the Indian soil.

\section{References:}

[1] Alsop, R and Hernsohn,N (2005) Measuring Empowerment in Practice:

[2] Aloysius P. Fernandez, (Fernandez, 2008). (Founder of MYRADA )

[3] CRDS: Chengalpattu Rural Development Society ( A-NGO)

[4] International Journal of Microfinance Volume.1 No.2011

[5] Naqvi,H (2008) “The Path of women's Empowerment in India”- Kurukshetra Volume,56.No.11, September ,pp 26-

[6] Nair, Tara S. (2010) "Commercial Microfinance and Social Responsibility" A Critique: Economic and Political Weekly.

[7] Priya Basu-2006," Improving Access to finance for India’s Rural Poor” Direction in Development, the World Bank, Washington DC.

[8] Stephen J.K. Selian A,"Role of NGO in Microfinance through SHGs"- Indian Journal of Marketing. Volume 8.August 2005

[9] Tyagi S. (2008) "Strategic Model for Effective functioning of SHG" - Kurukshetra. Volumw 57, No.2 Dec, PP 17-19.

[10] Thanni Raju, D and Deepa. M (2011) Capacity building of women Self Help Groups"

[11] Yunus, M (2007) "Creating a World without Poverty"

\section{Websites:}

- www.shy gate way .in.

- www.c gap.org

- wwW.gfusa.org

- www.micfingateway.com

- www.myrada,bangalore.co

- www,nabard.co

- www.nabard annual report

- RBI- www.rbi.in $3^{\text {rd }}$ March, 2009.

- www.tamilnaduwomen.org

- www.gdrc.org.

- www.kanchi.nic.in.

- www.velaisms.in

- www.ijrcm.org.in

- www.myrada.bangalore.com 